\title{
CCL25 Gene
}

National Cancer Institute

\section{Source}

National Cancer Institute. CCL25 Gene. NCI Thesaurus. Code C24779.

This gene is involved in the regulation of inflammatory processes. 